\title{
DOIS OU TRÊS DESVIOS ÉPICOS
}

TWO OR THREE EPIC DEVIATIONS

Luiz Philip Fávero Gasparete*

RESUMO: Este artigo se insere no campo das discussões sobre as manifestações populares nacionais a partir dos conceitos e dos conhecimentos oriundos da teoria literária. Mais precisamente, o trabalho tem como foco o debate a propósito de certo componentes dos desfiles das escolas de samba por conta de seus traços épicos. Inicialmente, será analisada a forma como a noção de gênero épico foi empregada, nos estudos sobre carnaval, para classificar as composições chamadas de samba de enredo. Convém demonstrar como essas aplicações são marcadas por certa imprecisão na compreensão do conceito, o que dificulta a diferenciação entre essas composições e o lirismo do samba urbano e o que remete a um equívoco recorrente, inclusive, nas teorizações sobre a literatura. Num segundo momento, a dimensão plástica e visual dos cortejos carnavalescos será pensada em função de características cruciais que constituem variações épicas em meio à dramatização da apresentação. Por fim, o texto esboçará a ideia de que a bateria das escolas, por causa de sua relação íntima com as religiões de matriz africana instituiria um desvio épico da percussão, elemento, a princípio, puramente rítmico.

PALAVRAS-CHAVE: escolas de samba; gêneros; épica.
* luizphilipfg@gmail.com

Mestrando do Programa de Pós-Graduação em Estudos Literários da Universidade Federal de Juiz de Fora (Juiz de Fora - MG).

ABSTRACT: This article falls within the field of discussions on national folk manifestations from the concepts and knowledge derived from literary theory. More precisely, the work focuses on the debate on certain components of the escola de samba parades due to their epic features. Initially, the way in which the notion of epic genre was used, in studies on carnaval, will be analyzed to classify the compositions called samba de enredo. It is important to demonstrate how these applications are marked by certain imprecision in the comprehension of the concept which makes it difficult to differentiate between these composition and the lyrict of urfer ins and the ly ricism of urban samba and what refers to a recuring misconception on the theorizations on literature. After that the plastic and visual dimension of the carnaval parades will be thought according to the crucial characteristics that constitute epic variations in the dramatization of the presentation. Finally, the paper will outline the idea that the baterias of the escolas de samba, because of the intimate relationship with Afro-Brazilian religions, would institute an epic deviation of the percussion, an element, at first, purely rhythmic.

KEYWORDS: escolas de samba; genres; epic. 
1 A CONTROVÉRSIA SOBRE O SAMBA DE ENREDO

Cartola e Carlos Cachaça compuseram um samba para o desfile de 1947 da Estação Primeira de Mangueira cujo título é "Brasil: ciência e arte". Apesar de não ter sido a escolhida para representar a escola de samba, a composição se tornou mais conhecida do que a vencedora esquecida talvez por ser menos bela e, consequentemente, menos famosa do que a perdedora, conforme Mussa e Simas (2010, p. 46). A letra, preterida à época e resgatada posteriormente, tem como foco principal a exaltação do Brasil por conta de seus artistas e cientistas. Um dado interessante que perpassa os versos é a antítese entre a glória dos grandes feitos celebrados ("epopeias triunfais") e a simplicidade dos meios utilizados para realizar a celebração ("neste pobre enredo").

O nome da música dos compositores mangueirenses ressoa no título dado por Mussa e Simas (2010) ao livro que escreveram sobre as peculiaridades históricas e estilísticas das composições destinadas aos desfiles carnavalescos: Samba de enredo: história e arte. Além da semelhança formal dos nomes, o estudo parece evocar o samba ao fazer uma separação entre as técnicas e os assuntos engendrados pelos sambas de enredo - o que remete à letra de Cartola e Carlos Cachaça - e ao escolher exemplos para construir a teoria em função de sua beleza poética e melódica, não de seu passado vitorioso - o que remete ao reconhecimento futuro da canção de 1947. Outra questão importante que decorre da proximidade sonora entre os títulos é o fato de, no trabalho de Mussa e Simas (2010), a história ser anteposta à arte, o que se reflete em um fator importante: as características essenciais do samba de enredo não são previamente apresentadas como um elemento consolidado e estabelecido, mas são destacadas com base nas variações e nas particularidades de suas manifestações ao longo da história, de modo que o conceito central se encontra subordinado às transformações estéticas pautadas por condicionantes e conflitos sociais que atuam profundamente no carnaval.

Com efeito, o momento mais teórico do livro, em que são descritos os dois conceitos complementares que possibilitariam a identificação de um samba de enredo, é inserido como um subcapítulo em que se abordam, inicialmente, as inovações do samba urbano a partir da década de 30. Nesse sentido, as escolas de samba teriam sido marcadas pela "mudança ideológica no mito do malandro" e pelo "interesse da cidade pelo samba do morro" (MUSSA; SIMAS, 2010, p. 22). Além disso, os autores demonstram como foi essencial para a consolidação do gênero musical em questão o estabelecimento da necessidade do enredo - o que indica a influência dos ranchos 
nos desfiles carnavalescos e a busca por apoio do poder público como via de legitimação da cultura das camadas populares (MUSSA; SIMAS, 2010, p. 17). Comuns nos ranchos, os enredos de "valorização de temas nacionais, personagens marcantes do Brasil e a exuberância da natureza brasileira" serviram às escolas como forma de conquistar a simpatia do Estado, com o nacionalismo típico da Era Vargas e seu projeto de controlar e disciplinar, sobretudo, as comunidades negras (MUSSA; SIMAS, 2010, p. 18)

É a partir dessas ideias que se delineia a primeira noção conceitual, cha mada por Mussa e Simas (2010, p. 24) de "conceito extrínseco". O samba de enredo seria, por esse critério, "a expressão poética do enredo apresentado no desfile", isto é, "poema musicado que alude, discorre ou ilustra o tema alegórico eleito pela escola". Tais definições sucederiam da compreensão do que é um enredo, a nalisado em função de duas acepções distintas. Sob uma perspectiva abstrata, um tema proposto e que não é julgado; sob uma perspectiva prática e ligada ao julga mento, o "desenvolvimento ou representação desse tema alegórico nas alegorias, adereços e fantasias" ou como "manifestação plástica do enredo abstrato”. Por analogia, surgiria uma terceira variação das descrições anteriores: o samba de enredo é a "forma lítero-musical" que se adequa ao assunto teórico e abstrato da primeira acepção.

A segunda noção conceitual utilizada é a de "conceito intrínseco" (MUSSA; SIMAS, 2010, p. 29). Esse critério depende, por sua vez, da concepção a propósito da "unidade constitutiva fundamental" da forma poética: o verso. No caso do samba, composição tanto poética como musical, o verso deveria ser pensado "em função do ritmo e da melodia” (MUSSA; SIMAS, 2010, p. 31) de forma que os compassos que configuram a métrica podem ou não ser preenchidos pela letra - daí a ideia de "verso vazio".

Nessa etapa da argumentação, Mussa e Simas (2010, p. 32-36) não estabelecem os elementos básicos da estrutura interna do gênero abordado, mas descrevem principalmente os traços elementares do partido-alto e do sa mba de terreiro, dos quais o samba de enredo sofre influência em sua cadência e dos quais deveria se diferenciar para evidenciar uma versificação própria. É notável que as composições pertencentes ao assim cha mado período de formação (década de 30 e começo da década de 40) ainda não tenham empreendido tal insurgência "contra o padrão vigente dos sambas de terreiro" (MUSSA; SIMAS, 2010, p. 38). Por conta disso, o critério intrínseco não é

Teoria, Crítica Literária, outras Artes e Mídias 
objetivamente explicado na etapa do livro que lhe é reservada - o que somente chega a se esboçar na análise do "samba-lençol" do Império Serra no de 1951, a partir do qual "passa a ser impossível confundir samba de enredo com qualquer outro gênero de samba" (MUSSA; SIMAS, 2010, p. 56). Tal suspensão indica a maneira como o conceito é acometido, na obra, por uma imprecisão justificada pela relevância das contingências históricas e pela flexibilidade da forma.

Somado ao caráter coerentemente lacunar das informações sobre o critério intrínseco, há outro detalhe que dificulta um entendimento exato e categórico a respeito das especificidades do samba de enredo. No prefácio intitulado "Profissão de fé", Mussa e Simas (2010, p. 9) defendem que as letras de música representariam uma das maiores manifestações da produção poética nacional principalmente por causa de sua ligação com os legados orais das tradições indígenas e africanas e com a poesia cantada da "Ibéria medieval". Em meio a essas criações, o samba de enredo seria uma tipologia exemplar e "impressionante", pois contraria a "tendência universal da música popular urbana" para o lirismo e "integra o maior complexo de exibições artísticas simultâneas do mundo moderno: o desfile das escolas de samba" (MUSSA SIMAS, 2010, p. 10). De resto, o fato mais excepcional residiria na constatação de que "o samba de enredo é um gênero épico" - o único genuinamente brasileiro e que não sofreu a "mínima influência de qualquer outra modalidade épica”.

A despeito dessas "considerações bombásticas", conforme a percepção dos próprios autores, em nenhum momento do livro a noção de gênero épico é discutida seja no momento mais teórico, seja na enumeração dos sa mbas que se enquadrariam melhor nessa tendência. A ideia de "épico" é usada, em suas aparições pontuais, somente como um adjetivo para qualificar composições ou desfiles. Isso pode ser observado, por exemplo, na análise da letra feita por Silas de Oliveira e Mano Décio da Viola para o Prazer da Serrinha em 1946: "a poesia começa a abandonar o lirismo, típico de todos os gêneros de música popular urbana, e assume um tom mais épico, reforçado pela densidade da melodia que passa a caracterizar o samba de enredo" (MUSSA; SIMAS, 2010, p. 43, grifo meu); ou no comentário sobre o samba "Seca do Nordeste" de Gilberto de Andrade e Valdir de Oliveira para a Tupi Brás de Pina em 1961, cujo enredo de protesto falava sobre um problema brasileiro: "desfile de escola de samba é coisa séria; e tem um alcance muito maior, tem um sentido épico que transcende o próprio carnaval" (MUSSA; SIMAS, 2010, p. 63, grifo meu). 
A indefinição sobre a compreensão do gênero épico não se reduz, entretanto, ao livro. Mussa (2013), em artigo na imprensa de nome sugestivo ("A poesia perdida dos sambas de enredo"), recorre à mesma problemática para criticar a decadência e o "estilo previsível e engessado das composições do carnaval de hoje”. No artigo, o autor faz uma revisão histórica a propósito da relação entre a lírica e a épica sem, contudo, determinar as características fundamentais da segunda. O que Mussa (2013) destaca é o fato de o samba de enredo se formar a partir dos seus "congêneres líricos", ao contrário do que ocorreu na história das literaturas universais, em que o declínio das manifestações épicas corresponde à "ascensão da lírica, com a consequente valorização do indivíduo e de sua expressão subjetiva".

No que concerne à trajetória do gênero próprio ao carnaval, nova mente as criações de Silas de Oliveira a partir de 1951 - notabilizadas pelas va riações métricas, pelas rimas aleatórias e pela regra da imprevisibilidade - são tratadas como marco inaugural do formato que se tornaria clássico e inconfundível. Tendo como base tal marco inicial, Mussa (2013) lista alguns dos principais sambas de enredo, independente das variações temáticas ou melódicas que se apresentaram, de modo que são elencadas produções diversas como as de Martinho da Vila - em que o "samba de enredo continua épico, mesmo com melodias mais leves" (grifo meu) - e as que acompanharam desfiles como o da União da Ilha de 1977 (o célebre "Domingo") - em que se narraram, "num modo épico, assuntos mais triviais, mais aptos a uma abordagem lírica ou satírica" (grifo meu). Aqui fica evidente como o adjetivo épico é utilizado indistinta mente para diferentes categorias e como melodias e assuntos a princípio desfavoráveis à tipologia não inviabilizam a epicidade. De tal ma neira que o efeito estético poderia ser sugerido tanto no âmbito formal (critério intrínseco) quanto no temático (critério extrínseco).

Numa chave divergente, Simas (2014) discorre sobre o tópico numa coluna a respeito de "Os sertões", samba criado por Edeor de Paula para o desfile de 1976 da Em Cima da Hora. Na coluna, em que se elogia a capacidade da composição de sintetizar e potencializar, com suas modulações tonais, a obra homônima de Euclides da Cunha, o caráter épico do samba de enredo é explicado por sua semelhança com a epopeia:

Em um livro que escrevi com Alberto Mussa, definimos o samba-enredo como um gênero épico. Ele não é lírico, subvertendo uma tendência universal da música popular urbana. A epopeia, por definição, é um longo poema ou narrativa em prosa, 
declamada ou cantada, que exalta os feitos memoráveis de um herói histórico ou lendário, representante de uma coletividade. É, ainda, o relato de um evento extraordinário, capaz de provocar surpresa e admiração. Ao contrário da lírica, nela não predomina o sentimento íntimo do poeta, mas o caráter de exaltação de grandes aventuras. (SIMAS, 2014, grifo meu)

Nessa passagem transparece uma concepção sobre a épica baseada no conteúdo da letra e na exigência da glorificação de personagens e fatos excepcionais. Simas (2014) revela, assim, um entendimento sobre o conceito que talvez esteja implícito às formulações de Mussa e Simas (2010) e que, todavia, não coincide integralmente com as ideias de Mussa (2013).

O impasse sobre o gênero épico por parte das referências que discutem o carnaval não se restringe aos dois autores citados. Góes (2009) recorre a uma perspectiva semelhante à de Simas (2014) para sustentar que, a partir da década de 70, houve uma substituição do épico pela crônica nos desfiles do Rio de Janeiro. Ao invés de "enaltecer acontecimentos relevantes ou vultos expressivos da nossa história", as composições desse período "tratam de aspectos cotidianos da vida brasileira" (GÓES, 2009, p. 244). A "feição croniqueira" das letras, que as aproxima das marchinhas e seus comentários críticos sobre o dia-a-dia, destoaria da "feição de epopeia" dos sambas que se alinhavam à "tradição da épica clássica” por conta dos assuntos grandiloquentes e da linguagem pomposa. Góes (2009, p. 246) atribui à União da Ilha um papel central nessa revolução por causa de dois desfiles dos a nos 70 - "Domingo" (1977) e "O a manhã" (1978) - e um do começo dos anos 80 - "É hoje" (1982). É curioso que o samba de enredo definido como ponto de virada e do suposto rebaixamento da épica ("Domingo") seja descrito por Mussa (2013), citado acima, como aquele em que se narrou, "num modo épico, assuntos mais triviais". A incompatibilidade entre argumentos e concepções é expressiva.

Raymundo (2011) recorre a várias referências para complementar teoricamente as reflexões de Mussa e Simas (2010) e para sustentar a tese de que o samba de enredo pertence, de fato, ao gênero épico. Nesse sentido, as ideias de Benjamin sobre a evolução e a crise da narrativa (apud RAYMUNDO, 2011, p. 36) permitiriam compreender as composições das escolas de sa mba como um resquício da tradição oral, o "patrimônio da épica", e como uma via de conservação da memória, "capacidade épica por excelência”. O pensamento de Tinhorão (apud RAYMUNDO, 2011, p. 38) garantiria a associação entre o "processo de composição" dos "sa mbistas 
semianalfabetos" e o dos "poetas clássicos desde a Ilíada, de Homero, até Os Lusíadas, de Camões". A teoria de Farias (apud RAYMUNDO, 2011, p. 39) reforçaria a relação entre o sa mba de enredo e as epopeias por se destinarem à oralidade, por empregarem a "grandiloquência" e a "exaltação de heróis", e por abarcarem o pla no histórico e o plano mítico. Por fim, a articulação de Schüler (apud RAYMUNDO, 2011, p. 40) indicaria a exploração da subjetividade como uma possibilidade épica dos sa mbas.

A compreensão do gênero épico por essas referências portanto, segue caminhos discrepantes e oscila entre o plano do texto (a narrativa, a organização dos versos) e o plano do conteúdo (os dados extraordinários, o misticismo, a história e a subjetividade). Raymundo (2011, p. 43), de sua parte, não chega a esclarecer tais divergências e busca verificar a pertinência das associações ao analisar um samba de enredo a partir da estrutura da epopeia (proposição, invocação, enumeração, etc.). De modo que, aí também, a essência épica do formato em debate permanece pouco consistente e precisa.

\section{EQUíVOCO METONÍMICO}

Rosenfeld (2014), embora sem se preocupar diretamente com o carnaval, faz uma revisão contundente sobre a história e os fundamentos do gênero épico. Já na
"Advertência" que antecede a obra, breves apontamentos antecipam a natureza das considerações e indicam alguns dos hipotéticos equívocos presentes na aplicação do conceito ao carnaval. A primeira questão é que o "termo épico", num sentido técnico, remete a "gênero narrativo" (ROSENFELD, 2014, p. 12, grifo do autor). Em segundo lugar, o autor afirma que epopeia não é sinônimo de épico, mas uma das espécies ou manifestações deste, assim como "o romance, a novela, o conto e outros escritos de teor narrativo".

Como convencionalmente se dá nesse tipo de explanação, a definição da épica é realizada em comparação e oposição à lírica e à dramática. Essa divisão, relativa às obras literárias, entre os três grandes grupos remontaria à República de Platão, em que a distinção dependeria, na esquematização já tendenciosa de Rosenfeld (2014, p. 15), dos graus de manifestação do poeta. No drama, constituído integralmente pela imitação, haveria o desaparecimento completo do poeta e a fala exclusiva dos personagens. Na lírica, ou algo próximo feito pelos ditirambos, haveria unicamente o relato do poeta. Nas narrativas, exemplificadas pelas epopeias, haveria ou poderia haver tanto a expressão do poeta ("nas descrições e apresentação dos personagens") como a expressão do personagem ("nos diálogos que interrompem a narrativa"). 
Uma segunda etapa dessas teorizações se deu, conforme Rosenfeld (2014, p. 16), com Aristóteles em sua Arte Poética, em que pouco teria sido acrescentado às teses da República. Nessa obra seminal, são mantidas as nuances e divergências entre os três gêneros em função dos tipos de imitação. A imitação "numa simples narrativa, ou pela introdução de um terceiro, como faz Homero" (ARISTÓTELES apud ROSENFELD, 2014, p. 16) seria própria ao gênero épico. A imitação "em que se insinua a própria pessoa (do autor), sem que intervenha outro personagem" (ROSENFELD, 2014, p. 16) estaria próxima do gênero lírico. Por fim, a imitação baseada na a tuação e na ação dos personagens seria própria ao gênero dra mático.

Ao dissertar sobre o gênero lírico em seus próprios termos, Rosenfeld (2014, p. 22) ressalta a voz central que "exprime um estado de alma" e expressa "emoções e disposições psíquicas, [...] concepções, reflexões e visões". Além disso, a lírica seria a "manifestação verbal imediata" das percepções e dos sentimentos gerados pelo encontro do "eu" com o mundo - o que justifica a "relativa brevidade do poema lírico" e, em contrapartida, a "extrema intensidade", inviável a uma "organização literá ria muito a mpla”. Tal concentração essencial impediria a "configuração mais nítida de personagens" e, ao reduzir a distância entre sujeito e objeto, a constituição do mundo objetivo (ROSENFELD, 2014, p. 23). Por fim destaca-se que a ausência de distância ta mbém concerne ao tempo, já que o pretérito se impõe como uma atualidade distendida e sentida no presente.

A propósito do gênero épico, Rosenfeld (2014, p. 24) sublinha, como contraponto à lírica, a emancipação do mundo em relação à subjetividade e o consequente apreço pela objetividade. Com efeito, o narrador - voz central e mediador decisivo do texto que pode ceder a palavra aos personagens - atua menos pela exibição interior do que pelo a to de narrar. Por conta disso, um efeito primordial da narrativa é a "distância entre o narrador e o mundo narrado" - mesmo quando é utilizada a primeira pessoa -, de tal maneira que seu tempo preferencial é o pretérito (ROSENFELD, 2014, p. 25). Outro desdobramento marcante desses dados constitutivos é a predileção pela função comunicativa por parte da linguagem épica, que depende da amplidão do universo construído. A partir das correspondências de Goethe e Schiller, Rosenfeld (2014, p. 32) ainda propõe que a épica prescinde do "encadea mento rigoroso" e recorre à "autonomia das partes", de modo que os "motivos retardantes", ava nços e retrocessos por exemplo, podem ser vistos como mecanismos épicos. 
No caso do gênero dramático, Rosenfeld (2014, p. 27) defende que, diferente da épica, que se estrutura a partir da oposição sujeito-objeto, ocorre um apagamento dessa oposição. Tal apagamento, que também marca a lírica em função do mundo completamente subjetivado, promove a aparição de um mundo absoluto e autônomo no drama. Trata-se, portanto, do desaparecimento de qualquer mediador, seja épico ou lírico. A autonomia dos fatos, que se apresentam de forma independente, teria como correlato indispensável a autonomia dos personagens, que impõem a força e a intensidade do gênero (ROSENFELD, 2014, p. 29). A via elementar de garantir a potência dos acontecimentos seria, nessa abordagem, o "rigoroso encadea mento causal" e a seleção dos eventos de acordo com as exigências internas da peça. De resto a ação dramática se desenvolve no tempo presente com caráter inédito e original, "sempre pela primeira vez" (ROSENFELD, 2014, p. 31).

Essas são, em linhas gerais, as ideias de Rosenfeld (2014) sobre os três grandes gêneros que o inserem numa tradição filosófica composta por nomes como Platão Aristóteles, Hegel, Goethe, Schiller, Lukács e Staiger, todos eles citados, com breves ressalvas, na sustentação dos argumentos. Com base nisso, é possível dizer que, para essa tradição resumida por Rosenfeld (2014), a essência do épico não está ligada à magnitude dos assuntos abordados ou a alguma especificidade relativa ao conceito extrínseco, nos termos de Mussa e Simas (2010). Tal essência tampouco está associada a uma questão puramente formal de orga nização dos versos ou do texto, a partir da métrica ou do ritmo, levando em conta puramente o critério intrínseco. O ponto crucial seria o tratamento narrativo dado a qualquer tipo de conteúdo externo e a utilização de recursos como o distanciamento entre o narrador e a matéria e como a amplidão e a autonomia das partes da narrativa. Mussa e Simas (2010, p. 24) chegam perto disso ao dizer que o samba de enredo "alude, discorre ou ilustra o tema alegórico", sem dar o devido relevo para o verbo "narrar".

Em um dos ensaios reunidos na importante publicação sobre As formas do épico, Pessanha (1992) concorda, em certo sentido, com as posições sintetizadas por Rosenfeld (2014). De saída, é mostrado como inclusive o sentido de epopeia, tomada por Simas (2013) como paradigma de criação que "exalta feitos memoráveis de um herói histórico ou lendário" e que relata eventos extraordinários, decorre da junção dos termos poiéo (fazer, criar) e épea (discurso, narrativa). De forma que a poesia épica seria, a rigor, a "palavra que narra algo em determinado tipo de verso"; ou em outras palavras: "do ponto de vista

Teoria, Crítica Literária, outras Artes e Mídias 
etimológico, epopeia é a criação narrativa em versos" (PESSANHA, 1992, p. 31). De modo a nálogo a Rosenfeld (2014), Pessanha (1992, p. 34) ainda afirma que a "marca fundamental, no estilo épico, é a distinção entre sujeito e objeto" e que a "estrutura em episódios", marcada por digressões e descrições, seria outra "característica funda mental” (PESSANHA, 1992, p. 36).

No entanto, Pessanha (1992, p. 34) ta mbém aponta que, na epopeia clássica, a matéria narrada e preexistente poderia ser considerada "relíquia de toda uma comunidade: o passado em sua dimensão histórico-mítica”. Daí a impressão recorrente de que a lembrança se volta para um "tempo arquetípico, tempo ideal e, por isso mesmo, merecedor de consagração". Somado a isso, nesses poemas clássicos, os personagens divinos e huma nos são colocados em grau de equivalência, o que faz destes protagonistas de uma "ancestralidade notável", de "memoráveis façanhas", e de qualidades de excelência (PESSANHA, 1992, p. 37). O desdobramento estilístico desses fenômenos seria a "grandiloquência" e a "adjetivação intensa", frequente nos "epítetos majestáticos" (PESSANHA, 1992, 38). Convém perceber, contudo, que esses traços dizem respeito às composições clássicas - e, não, aos fundamentos do gênero épico ou de uma das suas espécies mais célebres, a epopeia. Assim, caberia dizer que a compreensão sobre a épica é comumente acometida por um equívoco metonímico, em que as produções de um determinado período histórico são tomadas como modelo de um gênero perene que as supera.

Aceitos os posicionamentos acima priorizados, seria possível concluir, portanto, que o samba de enredo constitui, de fato, um desvio épico em meio ao lirismo da música urbana, mas não pelos motivos truncados por vezes apresentados. $\mathrm{O}$ esclarecimento conceitual sobre a épica, inclusive, poderia tornar as definições de Mussa e Simas (2010) mais consistentes. O critério intrínseco e o extrínseco não são suficientes para distinguir, em termo de gêneros, o sa mba de enredo de outras composições populares. Tal delimitação depende de um critério integralmente voltado para os modos de representação, com destaque para os métodos e procedimentos de trabalho com o conteúdo.

O cotejo dessas noções se estende, diga-se de passagem, a um campo fértil de tópicos correlatos. Trata-se da entrada dos sambas de enredo, como produto isolado e destacado do seu contexto de produção, na indústria fonográfica por meio de discos com coletâneas das composições de cada ano. Dotadas de uma autonomia característica das canções, as letras épicas pensadas para 
os enredos são inseridas num cenário em que o lirismo predominante já divide espaço com a narrativa e em que os gêneros tradicionais são notoriamente combinados e mesclados. Mussa e Simas (2010, p. 72) mostram como nos a nos 70, em que se dá essa inserção, a necessidade de a tingir um público maior e "não diretamente ligado às escolas de sa mba" faz com que a forma lençol seja abandonada, as letras sejam encurtadas e retomadas as estratégias dos sambas de terreiro. Não deixa de ser curioso que os autores considerem justamente esse o momento de "maturidade" do samba de enredo, por conta do "enriquecimento magistral dos recursos melódicos" e do "tratamento mais solto dos enredos", sem a obrigação do "tom altivo e lauda tório” (MUSSA; SIMAS, 2010, p. 74). Por outro lado, a transposição técnica gera um desdobramento a mbíguo, ligado à relação das criações com a oralidade. Segundo Faria (2020, no prelo), a popula rização massiva das composições propiciada pela difusão e pela gravação tem como efeito uma possível "permanência da canção popular para fora da tradição oral, ou seja, do corpo" - o que, no caso do carnaval, assume contornos expressivos.

\section{DIMENSÕES ÉPICAS DA ENCENAÇÃO}

As ideias de Rosenfeld (2014) sobre o "teatro épico" permitem ampliar as reflexões a nteriores sobre as manifestações épicas no conjunto de linguagens que compõe o carnaval. O pressuposto básico de uma colocação como essa é o de que sinais pertencentes a certo gênero podem se manifestar em criações pertencentes a outro. No que diz respeito aos desfiles carnavalescos, além das composições tipicamente épicas que são os sambas de enredo, haveria indícios épicos em outros componentes desse que é "o maior complexo de exibições artísticas simultâneas", conforme Mussa e Simas (2010, p. 10).

À imagem de Staiger e os mencionados Conceitos fundamentais da poética, Rosenfeld (2014) divide o significado dos gêneros em duas acepções: o significado substantivo e o significado adjetivo. A acepção substantiva, ligada à estrutura, remete à separação entre as obras de acordo com as peculiaridades constitutivas de cada um dos gêneros - a Lírica, a Épica e a Dramática (ROSENFELD, 2014, p. 17). A acepção adjetiva, ligada a evidências de materiais individuais e isolados, remete "a traços estilísticos de que uma obra pode ser imbuída em grau maior ou menor, qualquer que seja o seu gênero" (ROSENFELD, 2014, p. 18). De modo que um texto lírico possa, em tese, apresentar cunho dramático ou um texto épico possa, eventualmente, abarcar nua nces líricas. No caso estudado por Rosenfeld (2014), ressaltam-se as representações dramáticas que incorporam aspectos épicos. Na segunda concepção, portanto, "os termos adquirem grande 
a mplitude, podendo ser aplicados mesmo a situações extraliterá rias” (ROSENFELD, 2014, p. 19).

Não obstante a distinção entre as duas compreensões, a a nálise de produções baseada no campo adjetivo depende de um entendimento claro a propósito do campo substantivo, já que se torna fundamental, nesse tipo de leitura, identificar os elementos do gênero originá rio rasurados e os elementos pertencentes a outro gênero impostos. Assim, a noção de um teatro épico corresponde aos textos dra máticos ou encenações que incorporam características cruciais da épica, como o teor narrativo, a autonomia das partes, a simulta neidade de ações, a variedade de acontecimentos, o distanciamento, etc. É isso que faz, por exemplo, com que se indiquem marcas épicas nas peças históricas de Shakespeare, por conta das "introduções e comentá rios narra tivos" e do "parcelamento das cenas" (ROSENFELD, 2014, p. 71). Ou mesmo que possa ser identificado, a título de ilustração, um empuxo épico já no tea tro da Grécia antiga, por causa das intervenções narrativas do coro, que sugerem o ponto de vista do a utor e a esfera ritual da qual se origina a tragédia (ROSENFELD, 2014, p. 40).

Apesar dessas fases de ocorrências épicas pontuais nas peças teatrais, como também no tea tro barroco e no tea tro romântico, Rosenfeld (2014, p. 11) afirma que há dois "grandes momentos em que o teatro épico se manifestou em toda a sua plenitude”. Um desses momentos, mais próximo em termos temporais, seria o teatro moderno com suas diversas correntes, sobretudo o de Brecht, que conta com uma teorização fundamentada e consistente. Mais distante em termos temporais, o outro seria o teatro medieval, que, curiosa mente, teria desenvolvido vários procedimentos épicos análogos aos empregados pelas escolas de samba. É verdade que a apreciação do teórico se baseia numa redução excessivamente simplificadora das manifestações complexas que são as dramatizações medievais. A despeito disso, o delineamento esquemático oferece algumas chaves reveladoras para pensar o que interessa aqui, o carnaval brasileiro.

Nessa descrição do teatro praticado na Idade Média, Rosenfeld (2014, p. 43) mostra como o rito religioso, primordialmente a missa cristã e indiretamente os espetáculos pagãos e profanos, influenciou a montagem e a configuração das encenações. No caso do culto cristão, a própria "compreensão simbólica dos acontecimentos fundamentais do Evangelho" já seria causadora de um tipo de narração profundamente dramática e, no limite, de uma dramatização essencialmente narrativa. Em decorrência desse dado, as cenas criadas não passavam 
de "tropos' ou paráfrases que dra matizam" os eventos anteriormente contados (ROSENFELD, 2014, p. 44). A posterior inserção de elementos cênicos e a gradual ampliação espacial não deixariam de ter como núcleo gerador um relato de sentido previamente estabelecido pelo âmbito da religiosidade.

Ao acompanhar esses acréscimos e esse desenvolvimento, Rosenfeld (2014, p. 44) sublinha que, num estágio inicial, as ações teatralizadas estavam completa mente subordinadas ao ritual da missa e previstas, por rubricas, como momentos de passagem ao "desempenho". Além disso, os atos eram constantemente interrompidos por reflexões e "comentários lírico-épicos", de tal forma que os personagens estavam somente "semi-emancipados do contexto narrativo". O ponto de virada desse processo, em que o drama adquire certa independência, é viabilizado por alguns fenômenos: a apresentação da liturgia feita não por clérigos, mas por cidadãos; o abandono do espaço da igreja para a representação das peças; a "passagem do latim para a língua nacional de cada país"; a eliminação do narrador; a abordagem integral e extensa da vida de Jesus (ROSENFELD, 2014, p. 45). O termo dessa mudança é o surgimento do Mistério, que, em plena cidade, "ilustra a visão universal da história humana em a mplo contexto cósmico" e que, todavia, mantém o caráter épico do "acento cerimonial e festivo", por conta da "intervenção da música e dos coros".

A propósito da epicidade do teatro medieval, representado, sobretudo, pelo Mistério, Rosenfeld (2014, p. 45) explica que as manifestações são vastas e heterogêneas. O primeiro efeito épico seria gerado, em suma, pelo desejo de "narrar tudo", em detrimento da unidade e da concentração. Paralela mente, a "fusão do elevado e do popular", típica do cristianismo, e o direcionamento ao povo com função didática seriam inviáveis à tragédia clássica, o que representa uma ruptura com o próprio gênero dra mático (ROSENFELD, 2014, p. 46). A aparição de "numerosos personagens de origem e posição diversas" e, em consequência disso, a multiplicidade de perspectivas contrariam o rigor fechado do drama. Em última instância, a a mplitude temporal e a variedade de episódios, englobados no lugar unívoco da visão cristã, fazem com que se constitua uma vasta epopeia, "um conto dra mático ilustrado por cenários e personagens" (COHEN apud ROSENFELD, 2014, p. 47).

Um desdobramento estrutural importante de tais aspectos é o advento do "palco simultâneo" (ROSENFELD, 2014, p. 47). Em uma criação anterior chamada de "palco sucessivo", os carros, que possuía m ambientes múltiplos 
em representação de locais variados, apresentavam as cenas paralelas e se moviam "numa espécie de procissão dra mática”. O palco simultâneo, propriamente dito, consistia na disposição e justaposição de todos os cenários, lado a lado, na frente do público. Assim, era criada uma cena gigantesca em que todos os elementos já estavam evidenciados e expostos de antemão, de modo que os personagens e o público se deslocavam em função das ações. Somada à horizontalidade, a verticalidade era trabalhada pelo movimento, favorecido por "acessórios e máquinas engenhosas", "desde os abismos infernais a té o céu - movimento que abarcava o homem situado no pla no intermediário" (ROSENFELD, 2014, p. 48). A rigor, o sentido épico dessa estrutura diz respeito ao repouso da ação, à antecipação dos acontecimentos e à manifestação da essência, em oposição à aparência sucessiva, à sucessão dra mática (ROSENFELD, 2014, p. 49).

Por fim, Rosenfeld (2014, p. 50) comenta como a encenação "pré-ilusionista" do teatro medieval estava associada à atmosfera de culto ou festa e à participação do público na promoção e elaboração do espetáculo. Os atores leigos eram unicamente "portadores dos personagens", uma espécie de "intermediário" que dá suporte, sem o objetivo de "recriar ou encarnar" as figuras. Com a finalidade exclusiva de exibição do sagrado, a caracterização esquemática se intensificava pela representação de um só personagem por vários atores (ROSENFELD, 2014, p. 51). A "meta morfose incompleta", portanto, dependia da prescrição de gestos e atitudes convencionais e da distância entre o mediador e aquilo que é ilustrado.

É interessante que os supostos dados que levariam o teatro medieval a se estabelecer como uma materialização do tea tro épico "em toda a sua plenitude", nas palavras já citadas de Rosenfeld (2014, p. 11), sejam estilisticamente semelhantes a alguns fenômenos decisivos dos desfiles de escolas de samba. Mais precisamente, são equivalentes alguns procedimentos épicos utilizados nas aparentes representações teatrais da Idade Média e recursos notáveis da encenação visual que ocorre no carnaval. Não se trata, portanto, de sugerir continuidades estéticas entre duas expressões culturais tão diferentes, levando em conta as organizações sociais em que estão inseridas, e tão distantes no tempo. O que ocorre é que, nos dois casos, padrões de configuração reforçariam, similarmente, a epicidade de elementos a princípio dramáticos.

A "metamorfose incompleta" não é senão uma evidência do que se passa numa ala de desfile carnavalesco, em que um assunto (figura ou episódio) é apresentado 
por vários integrantes convencionalmente fantasiados, que se distanciam da interpretação ao dançar e cantar o samba. O movimento horizontal do cortejo em frente ao público, com a repetição ininterrupta das cenas, e a potencial verticalidade dos carros alegóricos são análogos aos métodos desenvolvidos pelo "palco sucessivo" e pelo "palco simultâneo". A a mplidão das narrativas, a diversidade dos eventos, o didatismo e a fusão do elevado e do popular se explicitam nos enredos abrangentes sobre a trajetória completa de heróis nacionais ou de personalidades do povo (MUSSA; SIMAS, 2010, p. 51). O abandono dos cultos sagrados sem deixar de lado o acento cerimonial e festivo pode ser observado claramente nos desfiles a céu aberto que conservam, por exemplo, a mitologia "dos candomblés de origem nagô (ou ioruba)" (MUSSA; SIMAS, 2010, p. 98). De resto, o núcleo narrativo de compreensão simbólica que o Evangelho significaria para o tea tro medieval remete à importância e à primazia do enredo narrativo na configuração plástica e dramática da escola.

Célebre pela atuação como carnavalesco à frente do Salgueiro a partir dos anos 60 e pelo trabalho de temas afrobrasileiros, Pamplona (2013) corrobora, em sua autobiografia, a inclinação épica dos componentes carnavalescos mais associados ao drama. Nessas memórias, é explícita a associação dos desfiles de carnaval, em sua dimensão performática, ao gênero dramático. Para Pamplona (2013, p. 91) a apresentação das "escolas de samba é também uma dança dramática, é mesmo um espetáculo, um auto-teatral”. Entretanto, a explicação sobre esse tipo de dança deixa entrever a subordinação da coreografia ao enredo e a importância do samba, como elemento essencialmente narrativo, para a exposição do tema. As manifestações de canto e dança de "caráter dramático" seriam aquelas que "contam uma história através do canto da música, feita especialmente e do desenvolvimento coreográfico realizado geralmente em forma de desfile (cortejo)" (PAMPLONA, 2013, p. 163).

Tal redução épica do aspecto dramático é ainda reafirmada e exemplificada por dois relatos do carnavalesco. O primeiro diz respeito ao entendimento, por parte dos integrantes das escolas, da noção de enredo. Pamplona (2013, p. 64) comenta, com certo espanto, o fa to de o termo ser interpretado não como ideia abstrata, mas como materialização efetiva: "os componentes cha mavam de enredo as alegorias e adereços. Quando perguntavam: 'nosso enredo está bonito' não estavam se referindo à história do enredo, mas ao seu visual plástico". Tal concepção recaía na ideia de que as alegorias "é que contavam a história" (PAMPLONA, 2013, p. 80, grifo meu) 
A substituição, aqui, evidencia o fator épico do recurso ilustrativo.

O segundo relato se associa à restrita e moderada teatralidade da dança, marcante para a epicidade. Ao discutir a a tribuição de alguns problemas da coreografia do desfile do Salgueiro de 1964 à bailarina e coreógrafa Mercedes Baptista, Pamplona (2013, p. 94) afirma: "foi uma grande besteira minha exigir que, em meio ao desfile, houvesse um momento teatral que eu acreditasse de impacto. A ação pode ser teatral, mas não pode ditar o componente em sua esponta neidade”. Assim, nessa ocorrência, a negação da contraparte épica da encenação, nos termos de Rosenfeld (2014), foi punida e penalizada como um afastamento do tipo de movimento que convém às alas de uma escola. $\mathrm{O}$ erro consistiu em contrariar uma das inovações, além do canto das baianas e do samba urbano carioca, que diferenciam o desfile de carnaval dos ranchos: "a dança espontânea" (SIMAS; FABATO, 2015, p. 19).

A partir desses exemplos e da comparação entre os prováveis meca nismos de representação engendrados pelo tea tro medieval e pelo carnaval, é viável postular que a encenação das escolas de samba é definida por traços narrativos, como a simultaneidade de ações, a variedade de eventos, a abrangência das histórias, o distancia mento e a submissão ao canto. Desse modo, se o samba de enredo constitui um desvio épico em meio à música popular urbana, as alegorias, alas, fantasias e coreografias dos desfiles constituem, por sua vez, uma vertente épica no conjunto das dramatizações possíveis. Em última análise, os dados que fariam do teatro medieval um momento exemplar do teatro épico, conforme Rosenfeld (2014), levariam a considerar que a dramatização dos cortejos carnavalescos é uma das variantes mais notáveis e populares desse tipo de teatralidade.

\section{DESVIOS E FRESTAS}

Como visto, Rosenfeld (2014) sublinha o "acento cerimonial”, por conta da música, e a integralidade da essência, por conta do palco simultâneo, como marcas épicas do tea tro praticado na Idade Média. Curiosa mente, o autor também tangenciou essas noções não só ao estudar o tea tro épico, mas ao discutir um assunto de profunda relevância e influência no carnaval das escolas de sa mba, de acordo com Mussa e Simas (2010): as religiões brasileiras de matriz africana. Em seu ensaio sobre a "macumba", inicialmente publicado em 1955, dez anos antes da primeira edição de $O$ teatro épico, Rosenfeld (2013, p. 49) investiga "costumes africanos que foram trazidos para o Brasil pelos negros" e "atos que ema nam de uma 
atitude mágico-mística”, com destaque especial para o Candomblé baiano. Na parte final desse texto, a análise da "festa" e da "função" da religião deixa transparecer uma concepção dos rituais baseada nas representações dramáticas de cunho épico.

Rosenfeld (2013, p. 68) afirma, a propósito das danças e possessões, que "não se trata propriamente de uma representação simbólica”. A festa seria, por essa via, uma unidade entre "celebração" e "origem", entre "símbolo" e "simbolizado", a partir da anulação da distância entre a exaltação do "acontecer divino" e o "próprio acontecer". Uma das razões dessa unificação dependeria da configuração musical e rítmica dos rituais e dos elementos que se ligam ao campo do drama e da épica, simultaneamente:

Cada deus é honrado com os cânticos e ritmos que lhe competem e executa sua dança com gestos altivos, conforme a mitologia. Pois quer a dança ritual descreva uma história divina, a representação dramática do acontecimento épico, que aconteceu em épocas primeiras e agora se torna o presente solene; quer o conto mítico nada mais seja do que uma interpretação posterior da explosão de sentimentos, a descarga motriz, a qual domada e enformada pela sociedade tornou-se expressão simbólica; seja como for, mito e ritual se implicam mutua mente e um está intima mente entrelaçado com o outro. (ROSENFELD, 2013, p. 67, grifo meu)

Rosenfeld (2013, p. 68) conclui que um dos componentes do Candomblé fundamentais para essas características seria a "percussão dos atabaques", que propicia a evocação mágica e o desenvolvimento da "primeva história das divindades na sagrada presença da cerimônia”.

Paralela mente, o papel social da religiosidade corresponderia a outro tipo de efeito épico. O êxtase, como transformação drástica, reservaria ao negro uma compensação pelos espaços impostos pela "sociedade organizada e dirigida pelo branco" e um abandono do "seu eu social, para, em obediência ao apelo desesperado dos ta mbores, transmutar-se no deus do trovão ou na senhora do mar" (BASTIDE apud ROSENFELD, 2013, p. 70). Numa chave estrutural, a transformação comunitária indicaria o apagamento dos limites "entre palco e plateia”, de forma que a narração ritualizada e passional do passado africano resguardaria um momento de reconhecimento em função de uma "cosmovisão fechada", embora a mbientada na "cultura branca". À maneira da dissolução das fronteiras entre público e atores no teatro medieval, o envolvimento crucial dos presentes constitui um mecanismo épico do ritual, pautado não só pelo 
tipo de encenação, mas principalmente pelo estímulo do tambor.

Simas (2019) desenvolve argumentos a nálogos com maior consistência e profundidade numa palestra em que privilegia a bateria das escolas de sa mba como elemento primordial de conservação da memória e de reconstrução de sociabilidade pelas comunidades diaspóricas, ta mbém cha madas de culturas de fresta. O princípio básico é o de que os ritmos desenhados pelos tambores, pensados e entendidos em função de uma gramática não-normativa, atuariam nas brechas das gramáticas normativas, pautadas pelo impulso disciplinador e pela sa nha de aniquilar a herança africana. As designações "culturas de síncope”, ligada à evidência da imprevisibilidade melódica, e "culturas de surdo de terceira", o surdo da bateria que se impõe no intervalo entre o tempo forte do surdo de primeira e o tempo fraco do surdo de segunda, estão ta mbém diretamente baseadas nesses pressupostos.

Segundo Simas (2019), a memória invocada pelo toque do ta mbor remonta ao tempo da ancestralidade e garante o sentimento de continuidade e pertencimento do grupo. Essa concepção recai sobre a ideia de que, além do acompanhamento rítmico, o tambor "conta histórias" em conformidade com seus diferentes códigos e "idiomas", ou seja, possui atributos épicos. Trata-se de uma vinculação entre narrativa e padrão rítmico oriunda das religiões de matriz africa na em que, por exemplo, o alujá de Xangô descreve a "história das grandes fogueiras" e o agueré de Oxóssi descreve as "grandes caçadas". É exatamente esse tipo de decodificação que leva Simas (2019) a reconsiderar e discutir alguns dos consensos repetidos pela historiografia das escolas de samba.

Simas (2019) mostra, nesse sentido, como é controversa a afirmação de que os enredos dos desfiles foram oficiosos em quase sua totalidade num primeiro momento. O caso da Portela, estudada por Simas (2012) em Tantas páginas belas, é utilizado para contestar opiniões dessa espécie. Batizada no dia 20 de janeiro, data em que é homenageado São Sebastião, padroeiro do Rio de Janeiro "a malgamado a Oxóssi", a bateria da Portela teria como fundamento de seu toque de caixa, que dá o traço característico de cada bateria, o agueré. De tal maneira que, mesmo quando falou da história oficial brasileira, como no desfile de 1953 sobre as "Seis datas magnas", a escola narrou, num discurso paralelo sustentado pelo ritmo, a caçada do orixá em uma mata africana. $\mathrm{O}$ caso da Mangueira ta mbém é citado para defender que a escola, desde 1932, conta o mito de Iansã por meio do toque de caixa inspirado no ilú, embora somente em 2016 a 
referência se torne explícita no nome do enredo: "Maria Bethânia: a menina dos olhos de Oyá". Tais informações permitem contradizer a concepção de que as agremiações foram, em grande parte de sua trajetória, agrupa mentos pretos que apresentaram narrativas brancas (SIMAS 2019).

A apresentação do Império da Tijuca de 2018 também é comentada por Simas (2019) para refletir sobre um dado já abordado acima, que tem como desdobramento um efeito épico: a dança dos integrantes. O enredo em questão tinha como título "Olubajé - um banquete para o Rei" e dava um destaque para a mitologia em torno de Omolu. Por causa disso, a bateria da escola sustentou, em seu andamento, o toque chamado de opanijé, que aparece na letra do samba e que evoca o ritual de dança e alimentação do orixá. Simas (2019) destaca como, no momento do desfile, os componentes "iniciados na macumba" dançavam de um modo peculiar, seguindo um código de movimentos prescrito pelo padrão rítmico. Essa ocorrência comprova como, à imagem do que Rosenfeld (2013) observou no Candomblé baiano, o tambor das baterias reúne a evocação mística e o envolvimento corpóreo dos participantes, que, na situação de um cortejo carnavalesco, pode operar um distanciamento entre intérprete e personagem representado.
Assim, com base no exposto, é plausível dizer que a bateria das escolas de samba, em sua proximidade com os rituais religiosos de matriz africa na, constitui um terceiro tipo de manifestação épica em meio aos cortejos carnavalescos. Se o sa mba de enredo representa um desvio narrativo na música popular e a encenação das alas e das alegorias introduz certo distancia mento e redução do elemento dramático, as variações, sobretudo, do toque de caixa podem ser vistas como um afasta mento da função puramente rítmica da percussão. Com efeito, o emprego do ritmo para narrar, de forma imanente, histórias de cunho religioso não obrigatoria mente subordinadas ao enredo e a dissolução rítmica da suposta fronteira entre palco e plateia são índices que remetem ao campo da épica, conforme a descrição de Rosenfeld (2013).

\section{REFERÊNCIAS}

FARIA, Alexandre Graça. A presença da canção na literatura brasileira. In: MENEZES, Roniere (Org.). Na literatura, as

músicas. Uberlândia: O sexo da palavra, 2020, no prelo.

GÓES, Fred. Samba-enredo: da epopeia à crônica. Textos escolhidos de cultura e artes populares, Rio de Janeiro, v.6, n. 1, p.243-248, 2009 
MUSSA Alberto A poesia perdida dos sambas de enredo $\mathbf{0}$ Globo, Rio de Janeiro, 09 de fevereiro de 2013.

MUSSA, Alberto; SIMAS, Luiz Antonio. Samba de enredo: história e arte. Rio de Janeiro: Civilização Brasileira, 2010.

PAMPLONA, Fernando. O encarnado e o branco. Rio de Janeiro: Novaterra, 2013.

PESSANHA, Nely Maria. Características básicas da epopeia clássica. In: APPEL, M. B.; GOETTEMS, M. B (Orgs.). As

formas do épico: da epopeia sânscrita à telenovela. Porto Alegre: Editora Movimento, 1992. p.30-39.

RAYMUNDO, Jackson. Samba-enredo, a canção do desfile de escolas de samba: um gênero épico brasileiro. 2011. 65fs. Monografia (Licenciatura em Letras) - Universidade Federal do Rio Grande do Sul, 2011.

ROSENFELD, Anatol. Macumba. In: Negro, macumba e

futebol. São Paulo, Perspectiva, 2013. p.49-71.

O teatro épico. São Paulo: Perspectiva, 2014

SIMAS, Luiz Antonio. Tantas páginas belas: histórias da

Portela. Rio de Janeiro, Verso Brasil, 2012.
O maior épico brasileiro. O Globo, Rio de Janeiro, 25 de fevereiro de 2014.

O que significa considerar a memória um direito? Sesc, São Paulo, 06 de junho de 2019. Disponível em $<$ https://www.youtube.com/watch?v=oU8BTghanBY>. Acesso em 06 de maio de 2020.

SIMAS, Luiz Antonio; FABATO, Fábio. Pra tudo começar na quinta-feira. Rio de Janeiro: Mórula, 2015.

Recebido em: 05-06-2020. Aceito em: 17-01-2021 